\title{
Vadybos žinių taikymas Lietuvos ūkininkų ūkiuose
}

\section{Dalia Vidickienè,}

\section{Rasa Melnikienė,}

\section{Živilè Gedminaitè-Raudonè}

Lietuvos agrarinès ekonomikos institutas,

V. Kudirkos g. 18-2,

LT-03105 Vilnius

El.paštas:dalia.vidickiene@laei.lt; rasa.melnikiene@laei.lt; zivile.gedminaite@laei.lt
Dinamiška žemès ūkio aplinka ir dèl klimato kaitos bei rinkų nestabilumo kylantys nauji iššǔkiai reikalauja iš ūkininkų žinių ir gebėjimų lanksčiai taikyti vadybos metodus ūkių veiklos tobulinimui. Straipsnyje pristatomas tyrimas, skirtas įvertinti vadybos žinių taikymo lygị Lietuvos ūkininkų ūkiuose bei parodyti taikomų vadybos metodų skirtumus atsižvelgiant ị ūkyje vykdomos veiklos pobūdị: ar ūkis vykdo tik pirminę žemès ūkio gamybą ir tiekia žaliavą perdirbamajai pramonei, ar prisitaikant prie naujai teikiamų rinkos galimybių imasi žaliavos perdirbimo, parduoda produkciją vartotojams, teikia paslaugas ir kitaip įvairina ūkio veiklą. Tyrimas buvo atliktas remiantis evoliuciniu požiūriu ị vadybos žinių taikymo raidą taikant sisteminès analizès ir anketavimo metodus. Tyrimo rezultatai patvirtino, kad vadybos žinių ịsisavinimas vyksta evoliuciniu būdu, pradedant nuo paprastesnių ir palaipsniui pereinant prie vis sudètingesnių metodų.

Raktažodžiai: evoliucinis požiūris, finansinès apskaitos duomenų analizė ir planavimas, operatyvinis ir taktinis planavimas, strateginis planavimas ir vadyba

\section{IVADAS}

Lietuvai atgavus nepriklausomybę ir igyvendinus ūkio privatizavimo reformą, žemès ūkyje taip pat ivvkko esminiai pertvarkymai. Privatizavus kolūkių ir tarybinių ūkių žemę, formavosi nauji organizaciniai vienetai, užsiimantys žemès ùkio veikla. Tik nedidelei daliai naujai susiformavusių ūkių èmè vadovauti asmenys, prieš tai buvę kolūkių ir tarybinių ùkių vadovais ar specialistais ir turintys žemès ùkio gamybai organizuoti reikalingų žinių bei igūdžių. Be to, net ir jiems trūko žinių apie rinkos ekonomiką. Su dar didesniu žinių trūkumu susidūrè žmonès, èmęsi ūkininkauti po restitucijos igyvendinimo atgautoje ar nusipirktoje žemèje. Dauguma jų atėjo ¡̇ žemès ūkio sektorių iš kitų veiklų ir neturejo tam tinkamo išsilavinimo, o praktinè patirtis, geriausiu atveju, buvo igyta sodybiniame 25-60 arų sklype.

Pirmaisiais dešimtmečiais daug ūkininkavimui reikalingų žinių teko igyti „klaidų ir bandymų“ metodu. Be to, igyvendinant ivvairias valstybès paramos kaimui programas buvo organizuota daug įvairių mokymų, skirtų ūkininkams, padedančių užkaišyti esmines žinių spragas apie ūkininkavimo sistemas. Daugiausia demesio buvo skiriama technologiniams gamybos organizavimo klausimams. Rinkos ekonomikai pritaikytų vadybos žinių poreikis nebuvo didelis, dauguma ūkininkų vertèsi su ekonominių ir vadybos žinių minimumu. Tai sąlygojo gana greitai susikūrusi pagrindinių žemès ūkio produktų supirkimo sistema, nereikalaujanti iš ūkininkų gerai išmanyti rinkodaros metodų. Be to, priešingai nei kituose ūkio sektoriuose, ūkininkams nereikèjo mokèti pajamų mokesčiu, taigi daugelis jų, ypač smulkesnieji ùkiai, netgi nevedè detalios savo veiklos apskaitos, atsiskaitinèdami grynaisiais nesudarinèjo raštiškų sandorių sutarčių. Padètis pradėjo keistis nuo 2009 m., kai prièmus LR gyventojų pajamų mokesčio įstatymo pakeitimus, ūkininkams bei jų partneriams atsirado prievole mokèti gyventojų pajamų mokestị, jei žemès ūkio valdos ar ūkio ekonominis dydis už praejusių metų mokestinị laikotarpi yra didesnis kaip 14 europinių dydžio vienetų (EDV) (nuo $2011 \mathrm{~m}$. pajamų mokestį moka ūkininkai, kurie yra pridètinès vertès mokesčio mokètojai). Lietuvos ūkininkams teko mokytis finansinès 
apskaitos plonybių, kartu padidejo domèjimasis vadybos metodais. Suprantama, atskirų ūkininkų turimų gebèjimų lygis ir požiūris į vadybos žinių reikalingumą valdant savo ūkị gerokai skiriasi. Dalis ūkininkų yra ịvaldę sudètingus strateginio valdymo ir vertinimo metodus, o dalis tebesilaiko skeptiško požiūrio netgi ị elementariausią apskaitos duomenų analizę. Skeptiku ateityje laukia dideli iššūkiai, nes poreikį Lietuvos ùkiuose ateityje taikyti vis sudetingesnius vadybos metodus sąlygos tiek bendrosios ekonomikos raidos tendencijos, tiek ir specifiniai procesai, keičiantys žemès ūkio verslą ir jo aplinką.

XXI a. verslo aplinka apibūdinama kaip labai dinamiška. Pokyčiai vyksta visose srityse: technologineje, ekonominejje, socialinejje ir aplinkosauginejje. Lyginant su praeito amžiaus paskutiniaisiais dešimtmečiais reikalavimai priimant verslo sprendimus iš esmès pasikeitè. Ekonomika tapo globali, taigi neužtenka išmanyti vietinę situaciją. Mèginant ịvertinti verslo sąlygas viso pasaulio kontekste vietoj informacijos trūkumo jaučiamas jos perteklius arba asimetriškumas. I pirmą vietą iškyla verslo imoniu gebejimas greitai ir lanksčiai prisitaikyti prie aplinkos pokyčių taikant ịvairias vadybos žinias. Ieškant būdų, kaip tai padaryti, netgi atsirado dinamiškų gebėjimų teorija, kuri teigia, kad įmonès turi jausti rinką, išnaudoti galimybes ir valdyti turimus išteklius dinamiškai, kad galètų išlikti pajègios nuolat diegti naujas vertès kūrimo strategijas (Teece, 2007). Anot teorijos autorių, dinamiški gebejimai, besiremiantys ne tik ịvairiomis verslo vadybos žiniomis, bet ir žinių vadybos metodų taikymu, turi būti laikomi pagrindiniu tvaraus konkurencinio pranašumo šaltiniu globalizuotose ir labai greitai besikeičiančiose rinkose (Teece et al., 1997; Eisenhardt, Martin, 2000; Teece, 2007).

Anksčiau aplinkos dinamiškumo sukeliamos problemos buvo labiausiai aktualios pramoneje ir paslaugų sektoriuje, tačiau pastaruoju metu su naujais iššūkiais, susijusiais su verslo sąlygų neapibrěžtumu ir nuolatine situacijos kaita, vis dažniau susiduria ir ūkininkai. Ekonomikos globalizacija ūkininkavimo sẻkmę daro vis labiau priklausomą nuo pokyčių maisto, energetinių ir kitų žemės ūkiui reikalingų išteklių rinkose (Cheshire, Woods, 2012). Be to, užsiimant žemès ūkio veikla, ypač aktualiu tampa gebejjimas susikurti strategiją, padedančią prisitaikyti prie naujo iššǔkio - klimato kaitos (Iglesias et al., 2012).
Jei anksčiau žemès ūkio sektoriuje didžiają dalị sèkmès lèmé technologinès žinios ir sugebejjimas organizuoti gamybos procesą, tai pastaruoju metu vis labiau auga vadybos metodų, apimančiuc visas vertès kūrimo grandinès dalis, išmanymo svarba. Kaip teigia B. Malcolm, „ateityje, priimdami sprendimus apie ūkininkavimo sistemas ir prekių bei finansų rinkas, ūkininkai turès galimybę gauti daugiau informacijos nei bet kada anksčiau. Tačiau žinių trūkumas ir netikrumas išliks pagrindiniais iššūkiais. Nepaisant galimybès reikiamu laiku gauti daugybę naujos informacijos, daug realybès aspektų išliks sunkiai suprantami“ (Malcolm, 2011. P. 73).

Pagrindiniai specifiniai procesai, keičiantys žemès ūkio verslą ir jo aplinką, yra susiję su ūkių veiklos diversifikacija ir stiprejančiu vartotoju poreikiu maitintis kokybiškais vietiniais maisto produktais. Žemès ūkis tampa daugiafunkcinis, taigi ūkininkams tenka igyti žinių ne tik apie žemès ūkio, bet ir apie kitokių ùkinių veiklų vadybą. Žemdirbių ūkių veiklos diversifikacija reikalauja universalesnių verslo vadybos žinių ir antrepreneriško požiūrio (McElwee, Bosworth, 2010). Lietuvos ūkių veiklos diversifikacija kol kas vyko tik epizodiškai, tačiau atsižvelgiant ì seniai rinkos ekonomiką turinčių šalių patirtị, netrukus bus pasiektas ir šis ūkių evoliucijos etapas.

Kita svarbi nauja tendencija, sąlygojanti nauju ūkininkų žinių poreikį, susijusi su žmonių požiūrio ił mitybą pokyčiais. Žemès ūkio industrializavimo pradžioje labai pažangiu laikytas intensyvus ūkininkavimas ir žemès ūkio mechanizavimas vis labiau kritikuojamas. Kai kurie autoriai pasisako ypač griežtai ir teigia, kad po Antrojo pasaulinio karo vyravęs agroindustrinis aprūpinimo maistu modelis patyrè krizę (Marsden, 2003, Van der Ploeg et al., 2010). Reiškiasi naujos maisto vartojimo tendencijos, kurios maisto rinką padalino $\mathfrak{z}$ dvi dalis. Nors didele dalis vartotojų vis dar orientuojasi i pigesnius maisto produktus, sparčiai auga vartotojų grupé, besirenkanti sveiką ir gamtai draugiškais būdais pagamintą maistą. Be to, prognozuojama, kad ši tendencija ateityje tik stiprès (European..., 2006). Dabartinė situacija ypač palanki Lietuvos ūkininkų mėginimams dalị žemès ūkio ir maisto produktų parduoti tiesiogiai galutiniams vartotojams, nes didejja ekologiško, šviežio, vartotojų gyvenamojoje vietoje pagaminto maisto paklausa. Kad sugebètų atsižvelgti ił vartotojų 
poreikius, sąlygotus konkrečios vietovès ypatumų, jie turi didinti savo vadybinius gebejjimus.

Straipsnio tikslas - įvertinti vadybos žinių taikymo lygi Lietuvos ūkininkų ūkiuose bei parodyti taikomų vadybos metodų skirtumus atsižvelgiant $\mathfrak{i}$ ūkyje vykdomos veiklos pobūdị: ar ūkis vykdo tik pirminę žemès ūkio gamybą ir tiekia žaliavą perdirbamajai pramonei, ar prisitaikant prie naujai teikiamų rinkos galimybių imasi žaliavos perdirbimo, tiesiogiai parduoda pagamintus produktus vartotojams, teikia paslaugas ir kitaip ịvairina ūkio veiklą. Tyrimas buvo atliktas remiantis evoliuciniu požiūriu ị vadybos žinių taikymo raidą taikant sisteminès analizès ir anketavimo metodus.

Anketuojant surinkta ir susisteminta informacija leidžia identifikuoti bendrą situaciją Lietuvos ūkininkų ūkiuose taikant vadybos metodus ir patvirtina evoliucinị jų raidos pobūdị. Tyrimo rezultatai gali pasitarnauti rengiant mokymų programas Lietuvos ūkininkams.

\section{TYRIMO METODIKA}

Vertinant apklausos rezultatus buvo remiamasi nuostata, kad vadybos žinios igyjamos palaipsniui - einant nuo paprastesnių metodų prie sudètingesnių. Evoliucinio požiūrio, teigiančio, kad neįsisavinus pagrindų, neįmanoma peršokti ił sudètingų metodų taikymą, logiką patvirtina ir empiriniai tyrimai. Dažniausiai cituojamas iš keturių etapų susidedantis verslo vadybos žinių ísisavinimo kelias (Gluck et al., 1982), išskiriantis didelèms korporacijoms būdingus raidos periodus, einant link sudètingų strateginio valdymo metodų taikymo.
Pirmajame etape įmonès vadybininkai pagrindiniu savo uždaviniu laiko įmonès biudžeto formavimą ir susitelkia ì lèšų, reikalingų ateičiai, paiešką. Sprendimai priimami remiantis vidinès situacijos, daugiausiai grindžiamos finansinių rodiklių analize, vertinimu, o veiksmų planavimo periodas dažniausiai apsiriboja vieneriais metais. Antrajame etape jau imamasi prognozemis paremto planavimo, besiorientuojančio ị ilgesni, keletą metų apimantị laikotarpit. Trečiajame etape vadybininkų dèmesys nukrypsta $\mathfrak{i}$ išorès veiksnius. Perèjimą prie sudètingesnių metodų dažnai paskatina nusivylimas prognozemis, taigi vadybininkai mègina atsižvelgti i verslui ịtaką darančius išorès veiksnius savo jègomis. Tik ketvirtajame etape imamasi strateginio valdymo metodų, ne tik atsižvelgiančių i i išorès keliamas grèsmes ir naujas galimybes, bet ir padedančiu formuoti tolesnes imonès veiklos strategines kryptis, parinkti įmonei tinkamiausius jų igyvendinimo būdus ir ịvertinti siūlomų pakeitimų poveikị. Kiti autoriai išskiria panašius vadybos žinių kaupimo ir naudojimo etapus, dažniausiai išskiriami biudžetinio planavimo, operatyvinio ir taktinio planavimo bei strateginio planavimo (vadybos) etapai (Davis, 1979; Bilgen, Ozkarahan, 2004). Evoliuciniu požiūriu besiremiantys autoriai akcentuoja, kad pradedama nuo paprastesnių, operatyvinio planavimo metodų taikymo, ir pamažu pereinama prie strateginio valdymo (Hitt, 1998; Bryson, 2012; Hunter, 2012).

Apibendrinus teorines įžvalgas šiuo klausimu ir atsižvelgiant ị Lietuvos žemės ùkio sektoriaus situaciją buvo iškelta hipotezé, kad ryškiausiai išsiskiria trys Lietuvos ūkininkų vadybos žinių taikymo raidos etapai (1 pav.):

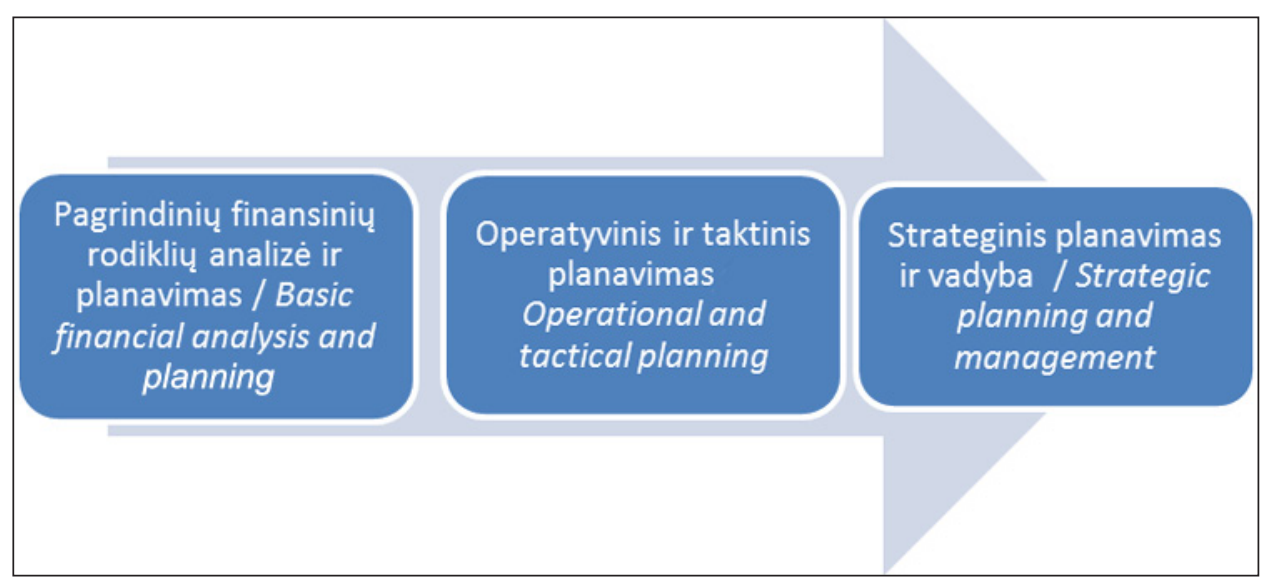

1 pav. Lietuvos ūkininkų vadybos žinių taikymo raidos etapai

Fig. 1. Phases of Lithuanian farms management practice evolution 
- Pagrindinių finansinių rodiklių analizè ir planavimas;

- Operatyvinis ir taktinis planavimas;

- Strateginis planavimas ir vadyba.

Pradejjus kurti privačius ūkius, veikiančius rinkos ekonomikos sąlygomis, svarbiausia buvo išspręsti su ūkio finansavimu susijusius klausimus. Ūkininkai buvo susitelkę í ūkio veiklos apskaitos metodų ịsisavinimą ir apskaitos duomenų panaudojimą vertinant ūkio pelningumą. Taigi, pradinị etapą galima apibūdinti kaip pagrindinių finansinių rodiklių analizès ir planavimo etapą. Kitas etapas susijęs su vadybos žinių panaudojimu planuojant savo veiklą, orientuojantis ị trumpą laikotarpi. Operatyvinio ir taktinio planavimo metoduc naudojimas padeda ūkininkui priimti sprendimus apie veiklos organizavimą per sezoną ar 1-2 metus. Trumpalaikių planų rengimas reikalauja domètis prognozėmis apie galimus žemès ūkio produktų ir gamyboje naudojamų išteklių kainų pokyčius, ieškoti veiklos gerinimo būdų pasinaudojant detalesne ir ịvairiai struktūruota apskaitos duomenų analize. Tik ísisavinus ūkio operatyvinio planavimo metodus, įmanoma pereiti prie sudètingo vadybininko uždavinio, orientuoto ị ilgalaikę verslo viziją, - strateginio planavimo ir vadybos.

Tyrimui atlikti buvo pasirinkta taikyti kiekybini tyrimų metodą, t. y. atrankinès apklausos metodą. Tyrimo duomenys surinkti naudojant klausimyną, parengtą atsižvelgiant $\mathfrak{i}$ tyrimui keliamus tikslus. Klausimai suformuluoti siekiant išsiaiškinti Lietuvos ūkininkų žinias apie populiariausius veiklos analizès ir tobulinimo metodus, padedančius priimti tinkamus ūkio vadybos sprendimus, ir jų naudojimo lygi.

Siekiant įvertinti pagrindinių finansinių rodiklių analizès ir planavimo taikymo mastą ūkininkų ūkiuose, buvo klausiama, ar planuodamas savo išlaidas ūkininkas analizuoja ūkio finansinius rodiklius ir naudoja ūkio pelningumo vertinimo metodus. Vertinant operatyvinio ir taktinio planavimo metodų taikymą ūkininkų ūkiuose buvo prašoma nurodyti, ar atliekamas atskiroms ūkio veikloms tenkančių išlaidų vertinimas (pvz., derliaus nuèmimui, produkcijos pardavimui, transportavimui ir pan.) bei būdų joms sumažinti paieška, pinigų srautų planavimas, ar analizuojami ūkio kintamųjų ir pastoviųjų išlaidų pokyčiai ir jų priežastys, domimasi gaminamos produkcijos rinkos kainų prognozemis ir imamasi veiksmų rea- guojant $\mathfrak{i}$ galimus žymius jų pokyčius. Klausimais apie strateginio planavimo ir vadybos metodu taikymą ūkininkų ūkiuose buvo siekiama išsiaiškinti, ar ùkininkai naudoja šiuos strateginius metodus: atlieka ūkio SSGG analizę; kuria ūkio veiklos alternatyvas ir atlieka jų palyginimą, pagrịstą skaičiavimais; domisi, kokioje situacijoje yra ūkio sektorius (šaka), kurioje ūkis veikia; lygina savo ūkio veiklą su panašiais labai sèkmingai veikiančiais ūkiais ir mégina pritaikyti ju patirtį; nagrinejja, kokie gaminamos produkcijos vartotojų poreikiai iki šiol nebuvo patenkinami; seka savo konkurentu veiklą bei planus ir imasi atsakomųjų veiksmų. Respondentų taip pat buvo prašoma nurodyti, ar jie taiko kokius nors kitus vadybos metodus savo ūkio veiklai organizuoti ir tobulinti, ir paminèti juos.

Apklausos rezultatai buvo analizuojami tikrinant dvi prielaidas. Pirmoji prielaida rèmési nuostata, kad veiklos analizès ir tobulinimo metodu naudojimo santyki tarp metodu taikymo ir jų netaikymo lemia ūkininkų suvokimo apie vadybos žinių vaidmeni ūkininkavimo sèkmei didèjimas ir metodų sudètingumas. Antroji prielaida sieké patikrinti, ar metodų taikymo mastas ir nuoseklumas, atsižvelgiant $i \mathfrak{j}$ ju sudètingumą, priklauso nuo ūkio vykdomos veiklos. Siekiant tai išsiaiškinti, buvo lyginami ūkių, kurie tradiciškai gamina žemès ùkio žaliavą perdirbamajai pramonei, ir ūkių, kurie neapsiriboja pirmine žemès ùkio gamyba ir diegia naujas veiklos alternatyvas, atsakymai $\mathfrak{i}$ anketos klausimus. Pastaroji grupè sudarė $22 \%$ visų respondentų.

Tyrimo, atlikto $2012 \mathrm{~m}$., metu apklausti 1105 Lietuvos ūkininkai, dalyvaujantys Lietuvos ūkiu apskaitos duomenų tinkle (toliau - ŪADT). ŪADT yra unifikuota visose ES šalyse veikianti informacinè sistema, atspindinti prekinę žemès ūkio produkciją gaminančiu ūkių veiklą. Ši sistema pradèjo funkcionuoti Europos ekonominëje bendrijoje kartu su bendrąja žemès ūkio politika. I ES ŪADT pagal visoms šalims vienodą metodiką atrenkami ūkiai, pagal tam tikrus požymius atspindintys atskiru šalių ūkių visumą (Ūkių..., 2012). Toks respondentų imties pasirinkimas užtikrino duomenų reprezentatyvumą ir patikimumą, nes ŪADT struktūra yra formuojama atsižvelgiant $\mathfrak{i}$ žemès ūkio surašymo ir žemès ūkio struktūros tyrimus siekiant parodyti Lietuvos prekinių ùkių, didesnių nei tam tikras ekonominis dydis, veiklos rezultatus. Kad būtų atspindèta ūkių visuma, respondentai yra parenkami 
pagal ekonominio dydžio klases ir ūkininkavimo tipus iš visų šalies administracinių rajonų. Anketas ÜADT respondentams išplatino ir surinko Lietuvos žemès ūkio konsultavimo tarnybos darbuotojai.

Didžiausią respondentų dalị sudare 40-49 metų amžiaus ūkininkai (35\%). Kitą respondentų dalị sudarè dvi grupès: 30-39 ir 50-59 metų ūkininkai, atitinkamai 24 ir 23 \% respondentų. Mažiausią respondentų dalị sudarè ūkininkai, kurių amžius iki 29 metu (8\%) ir vyresni nei 60 metų (10\%). Skirstant respondentus pagal lyti, $80 \%$ buvo vyrai, $20 \%$ - moterys. Daugiau negu pusè respondentu turi aukštesnijj ar specialujj vidurinị išsilavinimą (54 \%), $18 \%$ - vidurinị išsilavinimą. Didelè respondentų dalis turi aukštąj išsilavinimą - net $22 \%$. Nežymi respondentų dalis turi nebaigtą vidurinị ar pradinị išsilavinimą (atitinkamai 4 ir $2 \%$ ).

Pristatomam vertinimui atlikti naudoti bendri apklausos rezultatai, neskirstant respondentu i grupes pagal lyti, amžių, išsilavinimą. Rezultatų vertinimas pagal šias respondentų grupes bus atliekamas kitame tyrimo etape.

\section{TYRIMO REZULTATAI}

Pirmajame tyrimo etape buvo atlikta pagrindiniu finansinių rodiklių analizès ir planavimo, operatyvinio ir taktinio planavimo, strateginio planavimo bei vadybos metodų taikomumo šalies mastu struktūros analizè. Analizès rezultatai parodé, kad
1) dominuoja paprasčiausius metodus taikantys ūkiai, kuo sudètingesni vadybos metodai taikomi, tuo mažesnè tokių ūkių dalis; 2) visi sudètingesnius vadybos metodus naudojantys ūkiai taiko ir paprastesnius metodus (nè vienas ūkis, taikantis strateginès vadybos metodus, nenurode, kad netaiko bent keleto operatyvinio ir taktinio planavimo metodų, visi jie planuoja savo finansus, remdamiesi apskaitos duomenų analize). Tai patvirtino prielaidą, kad ūkininkai diegia vadybos metodus savo ūkiuose nuo paprastesnių metodų palaipsniui pereidami prie sudètingesnių, t. y. vyksta ūkininku vadybos žinių evoliucijos procesas.

Pagrindinių finansinių rodiklių analizès ir planavimo metodu taikymas. Apklausos metu gauti rezultatai parodé, kad didelè dalis Lietuvos ūkininkų, valdydami savo ūkị, nesugeba pasinaudoti finansinès apskaitos duomenimis. Ūkio pelningumo vertinimui ir planavimui finansinès apskaitos duomenų analizę nuolat naudoja tik mažiau nei puse $(47 \%)$ respondentų. $35 \%$ respondentų ùkio pelningumą analizuoja tik retkarčiais, o $18 \%$ - tokio metodo savo ūkyje apskritai netaiko. Tai rodo, jog net $53 \%$ respondentų neskiria nuolatinio dèmesio ūkio finansu planavimui. Šiu respondentų ūkiams kyla grèsmè, jog ūkio išlaidos viršys pajamas ir ūkiai patirs nuostolius.

Tyrimo rezultatai apie finansinès apskaitos duomenų analizès taikymą pelningumo vertinimui ir finansų planavimui pateikiami 2 pav.

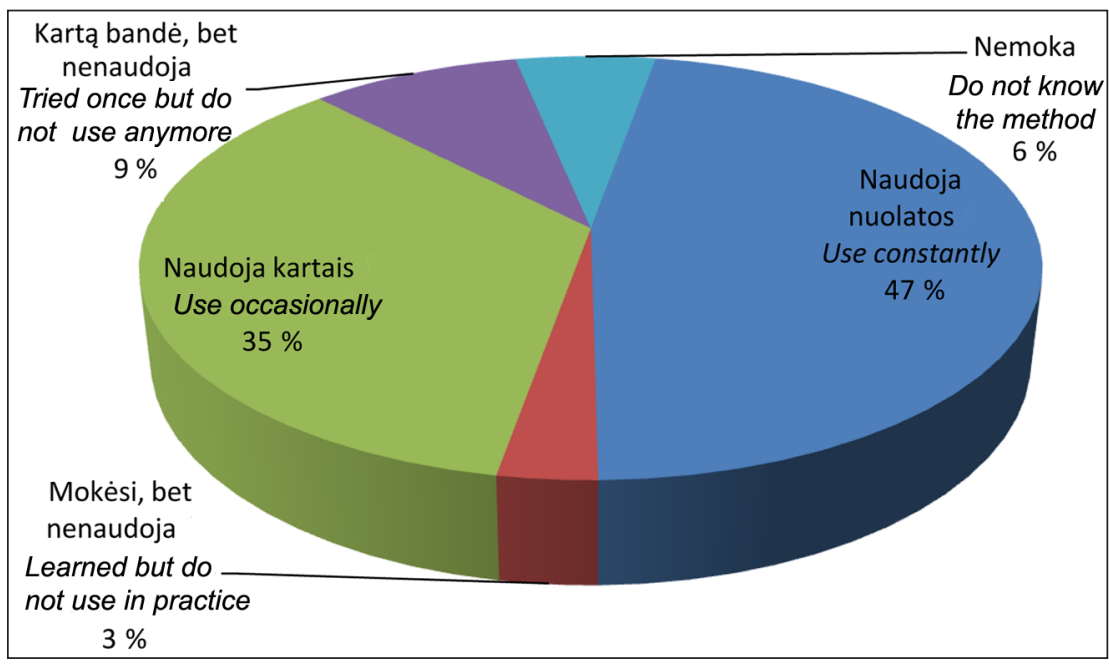

2 pav. Ükio veiklos pelningumo analizès ir finansų planavimo metodus naudojančių respondentų dalis \%

Fig. 2. Share of respondents using farm profitability analysis and basic financial planning methods, \% 
Operatyvinio ir taktinio planavimo metodu taikymas. Operatyvinio ir taktinio planavimo metodu naudojimo ūkiuose vertinimas parodé, kad daugelis šių metodų, kaip reikalaujantys papildomų vadybos žinių, ūkiuose yra taikomi rečiau nei finansinès apskaitos duomenų analizès metodai. Tik vienas metodas - rinkos kainų stebejjimas - yra gana plačiai paplitęs tarp respondentų, ir yra naudojamas net dažniau nei pagrindinių finansinių rodiklių analizès ir planavimo metodai. Net 73 \% respondentų rinkos kainų prognozes seka nuolat, o $19 \%$ ši metodą taiko kartais. Kiti operatyvinio planavimo metodai yra taikomi rečiau nei pagrindinių finansinių rodiklių analizès ir planavimo metodai. Ūkio išlaidų ir pajamų srautų planavimą nuolatos naudoja $31 \%$ respondentu, atskiroms veikloms tenkančiu išlaidų analizę nuolat naudoja 29 \% respondentų. Sudètingiausias tarp operatyvinio planavimo metodų ūkininkams yra kintamųjų ir pastoviųju išlaidų analizès metodas. Tik $22 \%$ respondentų ši metodą taiko nuolatos. Šio metodo iš viso netaiko taip pat didžiausia respondentų dalis - $44 \%$. Tyrimo rezultatai apie operatyvinio planavimo metodų taikymą respondentų ūkiuose pateikiami 3 pav.
Vertinant operatyvinio ir taktinio planavimo naudojimą ūkininku ūkiuose būtina atsižvelgti i aplinkybę, kad daugelis iš operatyvinio ir taktinio planavimo metodų negali būti taikomi nesusipažinus su finansinès apskaitos rodikliais ir nesuvokus jų įtakos ūkio veiklai. Todèl juos gali diegti tik tie respondentai, kurie planuoja finansu poreiki, remdamiesi pagrindiniais ūkio finansiniais rodikliais ir suvokia apskaitos vedimo naudą priimant vadybos sprendimus.

Operatyvinio ir taktinio planavimo metodus pradèję taikyti ūkininkai suvokia jų svarbą bei teikiamą naudą ūkio veiklos tobulinimui, nes dalis nuolat naudoja kelių metodų kombinaciją. 11,4 \% apklausoje dalyvavusių ūkininkų atsakè, kad jie nuolatos taiko visus 4 anketoje paminètus operatyvinio ir taktinio planavimo metodus, $10,7 \%$ respondentų savo ūkyje naudoja 3 iš minètų metodų, 19,7 \% respondentų atsakè, kad nuolat taiko 2 metodus, o $36,8 \%$ - 1 metodą. Tik $21,4 \%$ respondentų teigé, kad nuolat nenaudoja né vieno operatyvinio ir taktinio planavimo metodo.

Strateginio panavimo ir vadybos metodu taikymas. Strateginès vadybos metodų taikymas reikalauja iš ūkininkų ne tik savo ūkio situacijos

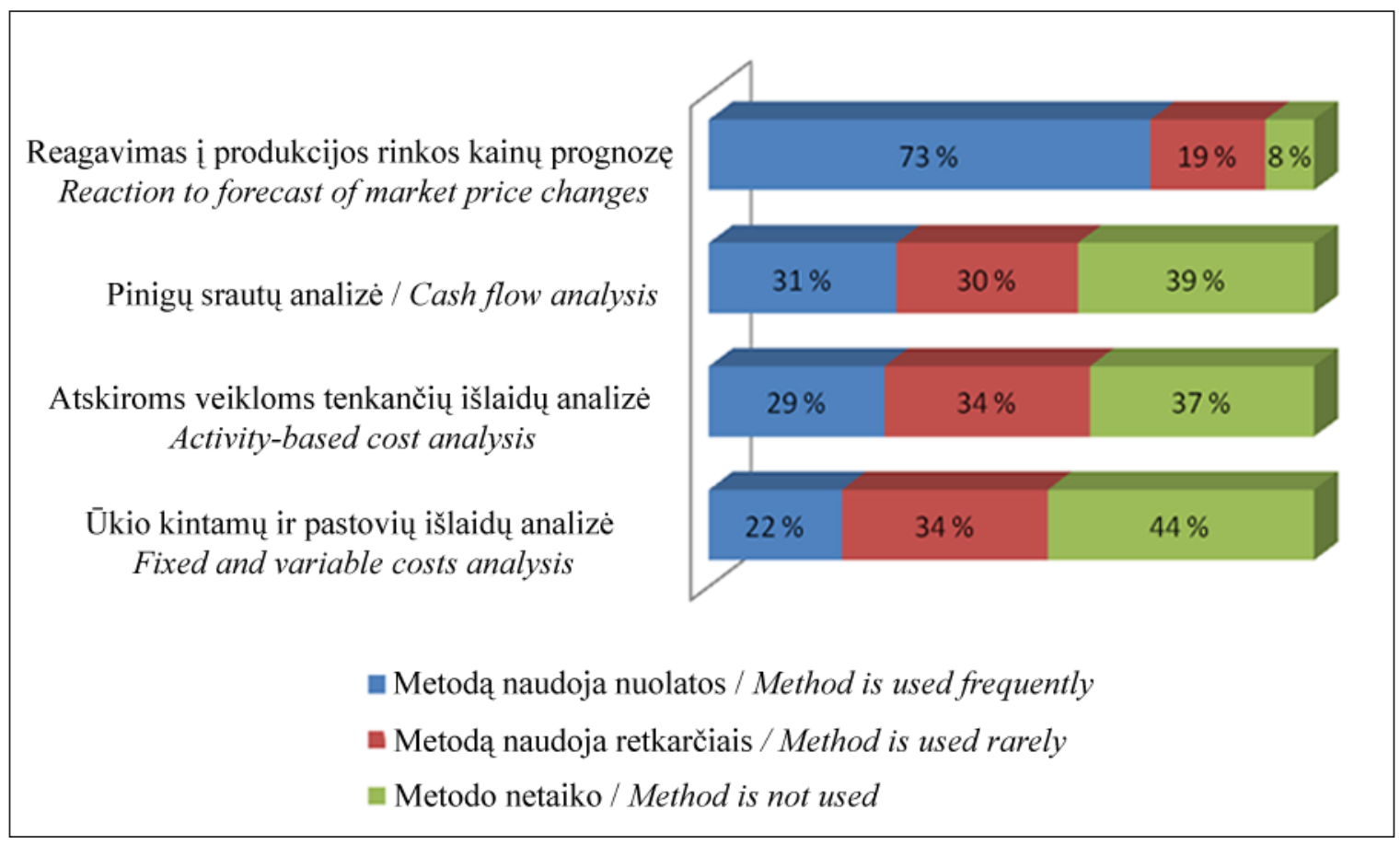

3 pav. Operatyvinio ir taktinio planavimo metodus taikančiu respondentų dalis \% Fig. 3. Share of respondents applying operational and tactical planning methods, \% 
išmanymo, bet ir gebejimo analizuoti bei vertinti išorinius veiksnius. Apklausa parodè, kad daugelis ùkininkų nesusidoroja su strateginès vadybos metodų taikymo iššūkiais, nes šie vadybos metodai yra paplitę respondentų ūkiuose rečiau nei kitų rūšių vadybos metodai. Populiariausias strateginès vadybos metodas - žemès ūkio sektoriaus analizé - $43 \%$ respondentų ši metodą taiko nuolatos, $39 \%$ - kartais. Toks dažnas šio metodo naudojimas yra susijęs su valstybės parama žemès ūkiui. Ūkininkai stebi vykstančius procesus, kad galètų pasinaudoti šios paramos teikiamais privalumais. Kiti strateginès vadybos metodai yra naudojamai daug rečiau. Ūkio veiklos lyginimo su panašiais sèkmingais ūkiais metodą nuolat naudoja $29 \%$ respondentų, besikeičiančius vartotojų poreikius analizuoja $16 \%$ respondentų. Tokia pat dalis - $16 \%$ respondentuc - lygina savo veiklą su panašiais sèkmingais ūkiais. Mažiausiai taikomi ùkio būklès ir jo aplinkos apibendrinimo reikalaujantys strateginiai metodai - ūkio SSGG analizè ir ūkio veiklos alternatyvų kūrimas bei ju lyginimas, paremtas skaičiavimais, šiuos metodus atitinkamai taiko 11 ir $8 \%$ respondentų.

Pagrindiniu finansiniu rodikliu analizès bei planavimo ir operatyvinių bei taktinio planavi- mo metodų taikymo praktikos analizè rodo, kad dalis ūkininku kai kuriuos metodus taikè nors retkarčiais, o strateginių metodų didesnè dalis respondentų visai netaiko. Didžiausiai daliai ūkininkų buvo sudètinga taikyti labiausiai situacijos apibendrinimo ir abstraktaus mastymo reikalaujančius ūkio SSGG analizès ir ūkio veiklos alternatyvų kūrimo metodus, atitinkamai 63 ir $73 \%$ respondentų. $52 \%$ respondentų neužsièmé konkurentų veiklos analize, $49 \%$ - visai nesidomejjo, kokios naujos galimybès atsirado rinkoje dèl nepatenkintų vartotojų poreikių.

Tyrimo rezultatai apie strateginès vadybos metodų naudojimą pateikiami 4 pav.

Tyrimo rezultatai parode, kad strateginio valdymo metodus ịvaldę ūkininkai suvokè jų svarbą ir palaipsniui diegè ūkyje po keletą šios grupès metodų. Kadangi šiems metodams pritaikyti reikia daug žinių, tai padaryti galèjo tik nedaugelis respondentu. Visus anketoje paminetus strateginès vadybos metodus sugeba taikyti tik $2 \%$ apklausoje dalyvavusių ūkininkų, 4-5 strateginès vadybos metodus taiko panaši respondentų dalis, atitinkamai $-3,9$ ir 3,8 \%. Kiek didesnè dalis respondentų taiko 3 metodus - 7,7 \%. Didžiausia dalis respondentų taiko tik $2(14,4 \%)$ ar 1

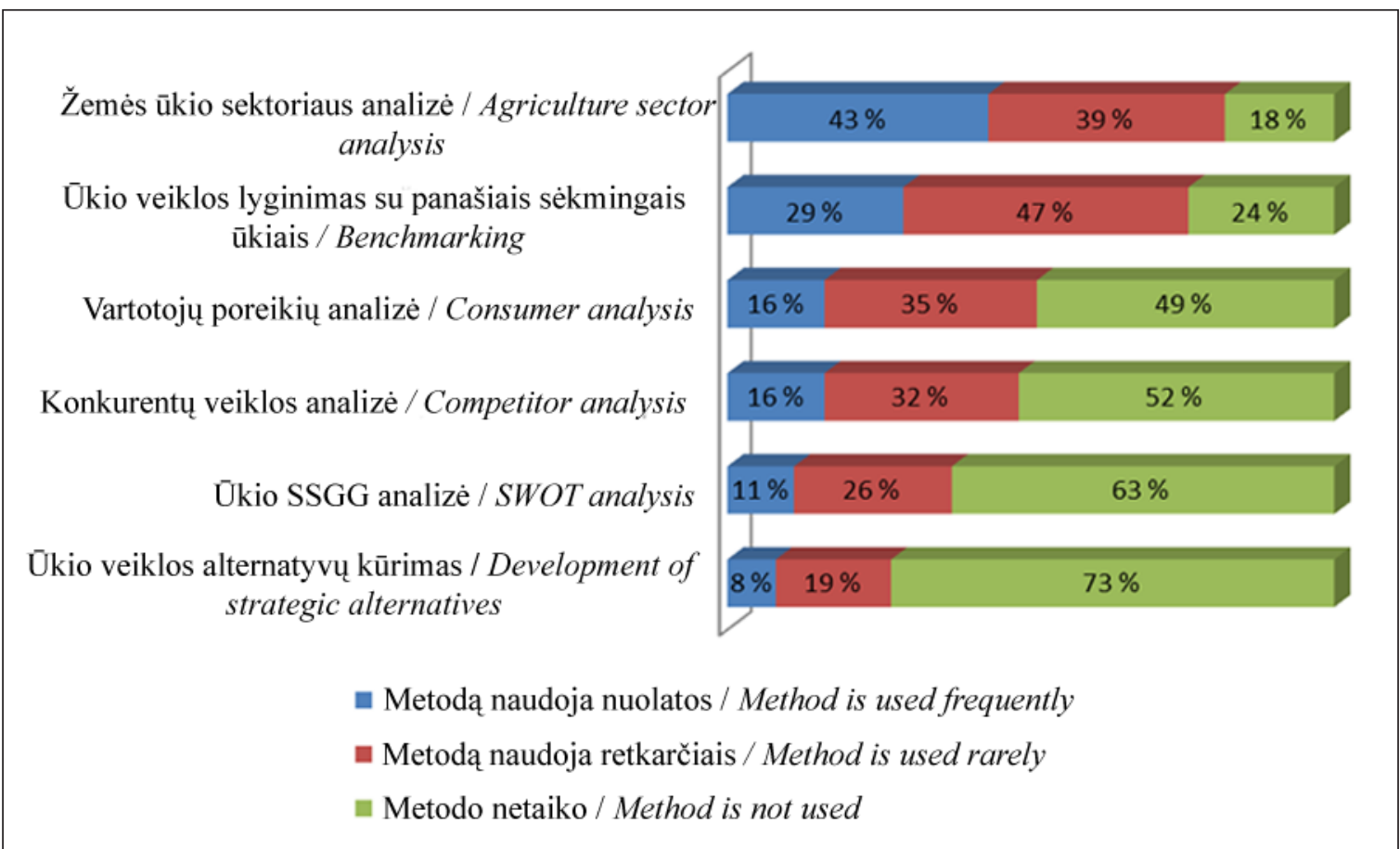

4 pav. Strateginès vadybos metodus taikančių respondentų dalis \%

Fig. 4. Share of respondents applying strategic management methods, \% 
metodą (24,3 \%). Né vieno metodo netaiko $43,9 \%$ respondentų.

Antrajame tyrimų etape buvo tikrinama prielaida, kad ūkių veiklos îvairinimas didina poreikị diegti sudètingesnius vadybos metodus. Šiam tikslui buvo analizuojami atsakymai, suskirsčius respondentus ị dvi grupes: ūkininkai, kurie užsiima tik žemès ūkio gamyba (I grupè) ir ūkininkai, kurie vykdo keletą veiklų, t. y. greta žemès ūkio gamybos užsiima produkcijos perdirbimu ir patiekimu rinkai bei teikia ịvairias paslaugas (II grupè).

Pagrindinių finansinių rodiklių analizès ir planavimo metodų taikymas. Lyginant I ir II grupei priskirtų respondentų atsakymus, gauti rezultatai parode, kad apskaitos duomenis pelningumo analizei ir finansu planavimui aktyviau taiko ūkiai, kurie ịvairina veiklą. 54,6 \% šios grupès respondentų nuosekliai taiko ši paprasčiausią vadybos metodą, kai tarp I grupés respondentu tokių yra 45,3\%. Pagrindinių finansinių rodiklių analizès ir planavimo metodų visai netaikančių respondentų dalis abiejose grupèse buvo panaši. Tyrimo rezultatai apie apskaitos duomenų naudojimą pelningumo vertinimui ir finansų planavimui I ir II grupès respondentų ūkiuose pateikiami 5 pav.
Operatyvinio ir taktinio planavimo metodu taikymas. Tyrimo duomenys rodo, kad II grupei priskirti respondentai aktyviau nei I grupès taiko visus operatyvinio planavimo metodus. Labiausiai skyrèsi I ir II grupès respondentų metodų, skirtų ūkio pinigų srautų planavimui, pastoviųjų ir kintamųjų išlaidų analizei bei atskiroms veikloms skirtų išlaidų analizei, taikymo mastas. Ūkio pinigų srautų planavimą savo ūkiuose nuolatos taikè 36,6 \% II grupès ir 29,9\%. I grupès respondentų, atskiroms veikloms taikančių išlaidų analizę - 36,6 bei $26,4 \%$ atitinkamų grupių respondentų, o pastoviųjų ir kintamųjų išlaidų analizès metodą ūkiuose nuolatos naudojo 28,4 ir 20,2 \% atitinkamų grupių respondentų. Taip pat didesnè dalis II grupés respondentų skyré nuolatinị dėmesi rinkų kainu prognozèms, nors ši informacija yra reikšminga ir I grupès respondentams.

Poreiki aktyviai taikyti operatyvinio ir taktinio planavimo metodus veiklą įvairinančiuose II grupei priskirtuose ūkiuose galima paaiškinti sudètingesne šių ūkių veiklos organizacine struktūra. Vykdant keletą veiklų būtina planuoti kiekvienos veiklos išlaidas bei pajamas, užtikrinant ūkio mokumą ir likvidumą, reikia analizuoti, kaip naujai veiklai reikalingos investicijos padidins išlaidas.

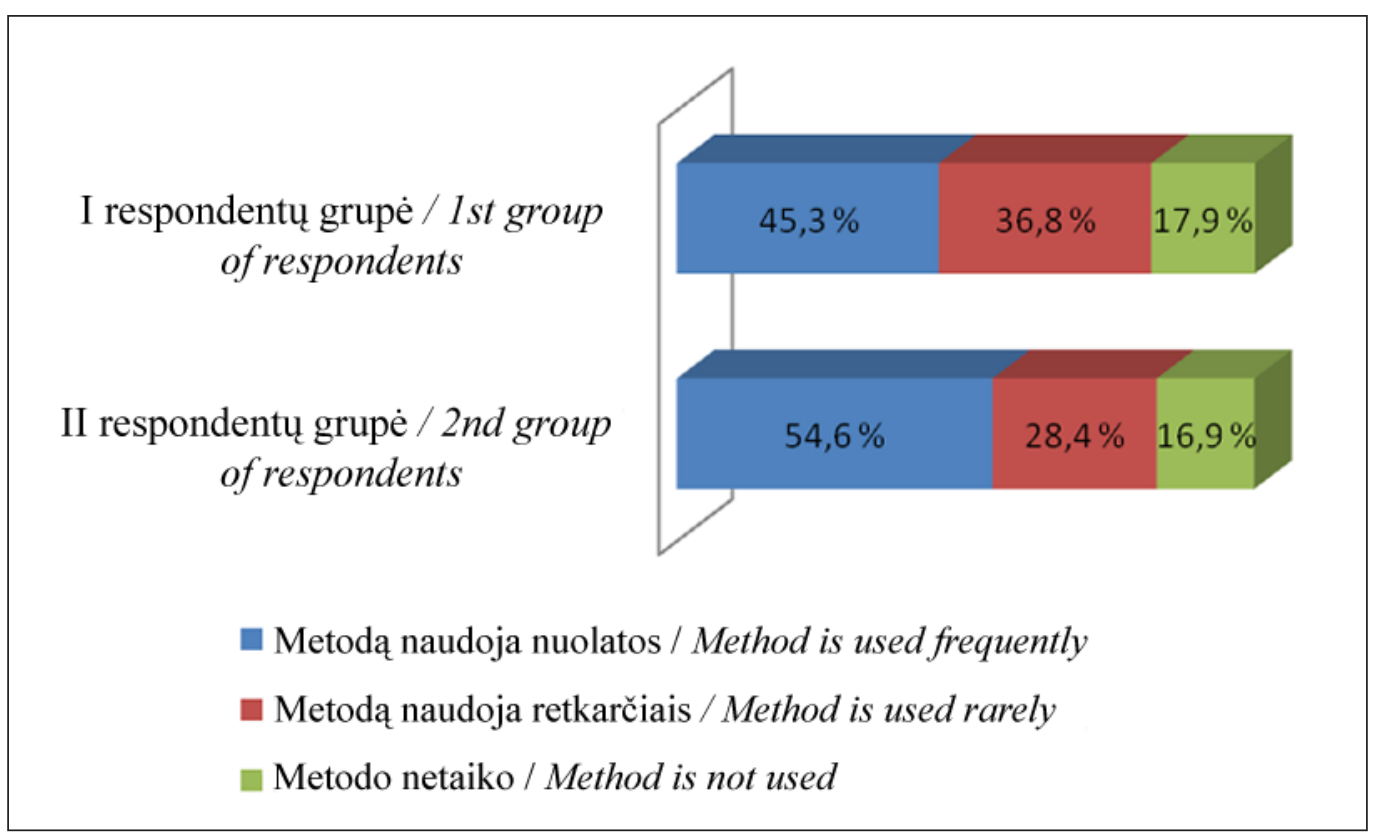

5 pav. I ir II grupès respondentų, naudojančių apskaitos duomenis pelningumo analizei ir finansų planavimui, dalis \%

Fig. 5. Share of respondents in 1st and 2nd groups using basic financial planning, \% 


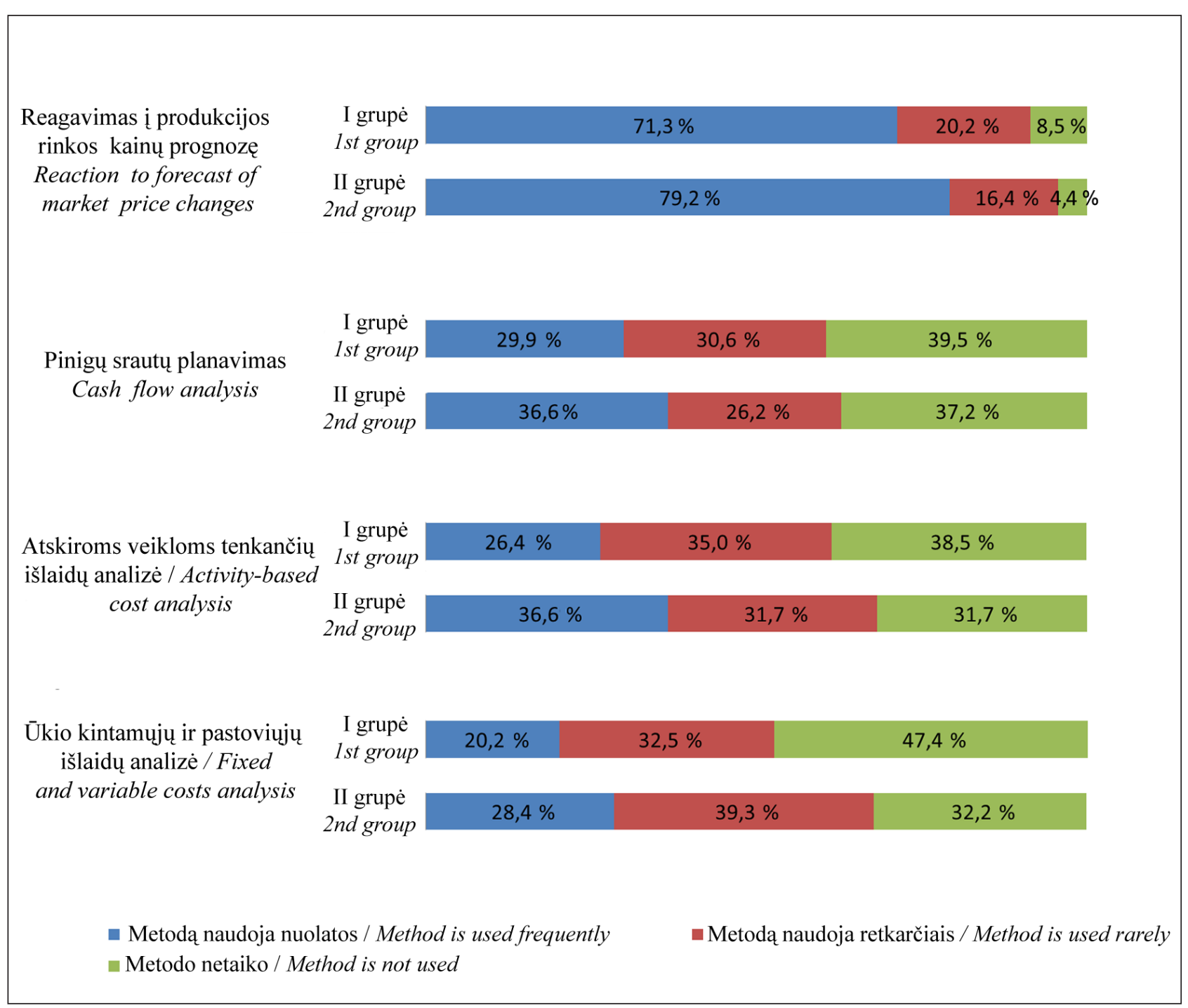

6 pav. I ir II grupès respondentų, taikančių operatyvinio ir taktinio planavimo metodus, dalis \%

Fig. 6. Share of respondents in 1st and 2nd groups applying operational and tactical planning methods, \%

Tyrimo rezultatai apie operatyvinio ir taktinio planavimo metodų taikymą I ir II grupès respondentų ūkiuose pateikiami 6 pav.

Strateginès vadybos metodų taikymas. Analizuojant strateginio planavimo ir vadybos metodų taikymą, tyrimo rezultatai taip pat rodo ūkių veiklą ịvairinančių ūkininkų pranašumą šioje srityje, palyginti su vien tik žemès ūkio veiklą vykdančiais ūkininkais. Daugelị strateginès vadybos metodų II grupès respondentai taikè savo ūkiuose dažniau nei I grupès respondentai, naudodami juos nuolatiniam veiklos tobulinimo procesui igyvendinti: 48,6\% respondentų skyrè nuolatini dèmesį konkurentų veiklai bei planams, 39,3\% atsižvelgè í produkcijos vartotojų poreikius, 30,9 \% stebèjo žemès ūkyje vykstančius procesus,
24,6 \% lygino savo veiklą su panašiais sèkmingai veikiančiais ūkiais. Iš I grupès respondentų minètus metodus nuolatos taikè atitinkamai 41,0, 26,7, 13,2 bei 14,0 \%. Mažiausiai respondentai taike SSGG analizès bei ūkių veiklos alternatyvų kūrimo ir palyginimo metodus. Kad nuolat naudoja SSGG analizès metodą, teigè maža I ir II respondentų dalis (10,6 ir 11,5\%), o ùkių veiklos alternatyvų kūrimą ir palyginimą taike po $16,4 \%$ I ir II grupès respondentu. Tai rodo, kad didžioji tiek I grupès, tiek II grupès respondentų dalis yra nepasirengę igyvendinti ilgalaikị strateginio planavimo procesą.

Tyrimo rezultatai apie strateginès vadybos metodų taikymą I ir II grupés respondentų ūkiuose pateikiami 7 pav. 


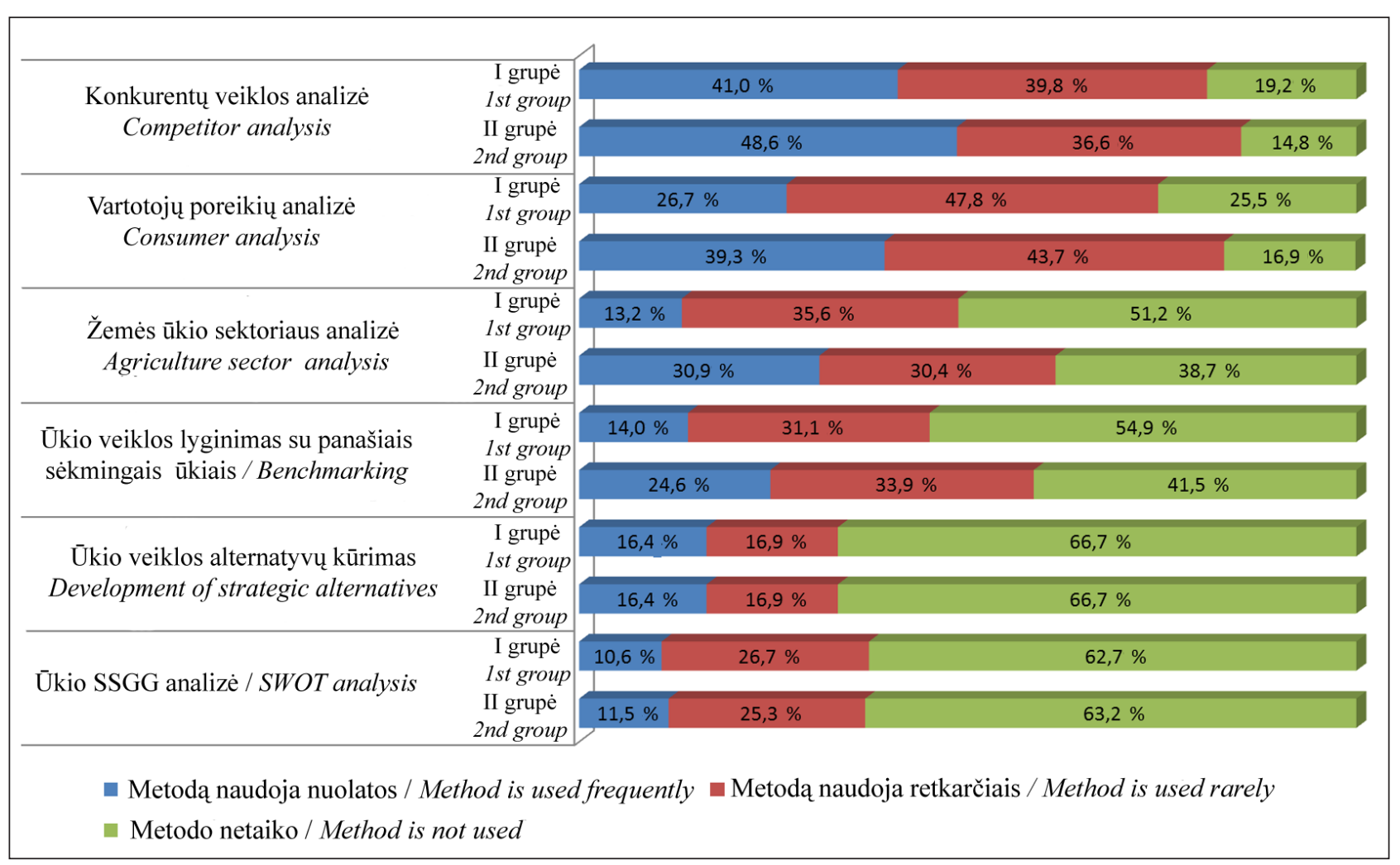

7 pav. I ir II grupès respondentų, taikančių strateginės vadybos metodus, dalis \%

Fig. 7. Share of respondents in 1st and 2 nd groups applying strategic management methods, $\%$

\section{IŠVADOS IR PASIŪLYMAI}

1. Tyrimo rezultatai patvirtino, kad vadybos žinių taikymas Lietuvos ūkininkų ūkiuose vyksta evoliuciniu būdu - pradedant nuo paprastesnių ir palaipsniui pereinant prie vis sudètingesnių metodų. Daugiausiai Lietuvos ūkininkų naudoja pagrindinių finansinių rodiklių analizès ir planavimo, mažesniu mastu - operatyvinio ir taktinio planavimo metodus, mažiausiai - strateginio planavimo ir vadybos metodus. Naudojantieji strateginius metodus moka bei nuolat naudoja ir paprastesniuosius - pagrindinių finansinių rodiklių analizès bei planavimo, operatyvinio ir taktinio planavimo metodus.

2. Tyrimo metu pasitvirtino hipotezè, kad savo ūkių veiklą ìvairinantys ūkininkai naudoja daugiau vadybos metodų nei ūkininkai, kurie gamina tik žemès ūkio produkciją. Veiklą diversifikavę ùkininkai aktyviau taiko visų trijų grupių: pagrindinių finansinių rodiklių analizès ir planavimo, operatyvinio ir taktinio planavimo bei strateginès vadybos metodus.
3. Žinios taktinio planavimo ir strateginès vadybos srityje yra svarbus veiksnys, galintis padrąsinti ūkininkus imtis alternatyvios žemès ūkio veiklos, kuri leistų jiems sumažinti ūkio veiklos riziką ir pagerinti ùkio veiklos rezultatus.

4. Organizuojant mokymus ūkininkams būtina ivvertinti ùkininkų patirtị taikant vadybos metodus ükyje, o mokymo procese pateikti vadybos žinias, laikantis evoliucinio požiūrio, t. y. atsižvelgti ị metodų sudètingumo laipsnị ir siekiant didesnio žinių ísisavinimo pradetti mokyti nuo paprastesnių vadybos metoduc ir tik po to pereiti prie sudetingesnių.

5. Gilinantis ỉ šią temą ateityje būtų įdomu patyrinèti, kiek svarbu, kad su vadybos metodais būtų susipažinęs ùkio savininkas, nes Lietuvos ūkių finansinei apskaitai vesti pasitelkiami buhalteriai dažniausiai apsiriboja ataskaitų parengimu, neduodami jokių patarimų dèl ùkio veiklos tobulinimo. 


\section{LITERATŪRA}

1. Bilgen B., Ozkarahan I. 2004. Strategic tactical and operational production-distribution models: a review. International Journal of Technology Management. Vol. 28(2). P. 151-171.

2. Bryson J. M., Alston F. K. 2012. Creating Your Strategic Plan. 3rd edition. San Fransicso: A Willey Imprint.

3. Cheshire L., Woods M. 2012. Globally engaged farmers as transnational actors: Navigating the landscape of agri-food globalization. Geoforum. Vol. 44. P. 232-242.

4. Davis R. K. 1979. Strategic, tactical, and operational planning and budgeting: a study of decision support system evolution. MIS Quarterly. Vol. 3(4). P. 1-19.

5. Eisenhardt K. M., Martin J. A. 2000. Dynamic capabilities: What are they? Strategic Management Journal. Vol. 21(10-11). P. 1105-1121.

6. Trends and Drivers of Change in the Food and Beverage Industry in Europe: Mapping Report. 2006. European Foundation for the Improvement of Living and Working Conditions [žiūrèta 201301-31]. Prieiga per internetą: <http://www.pedz. uni-mannheim.de/daten/edz-ma/esl/06/ef0637_ en.pdf>

7. Gluck F., Kaufman S., Walleck A. S. 1982. The four phases of strategic management. Journal of Business Strategy. Vol. 2(3). P. 9-21.

8. Hitt M. A., Keats B. W., DeMaiie S. M. 1998. Navigating in the new competitive landscape: Building strategic flexibility and competitive advantage in the 21 st century. Academy of Management Executive. Vol. 12(4). P. 22-42.

9. Hunter M. 2012. The Evolution of Business Strategy [žiūrèta 201303 18]. Prieiga per internetą: <http://www.wiwi-online.de/fachartikel. php?artikel $=517>$

10. Iglesias A., Quiroga S., Moneo M., Garrote L. 2012. From climate change impacts to the development of adaptation strategies: challenges for agriculture in Europe. Climatic Change. Vol. 112(1). P. 143168.

11. Marsden T. 2003. The Condition of Rural Sustainability. Uitgeverij Van Gorcum.

12. McElwee G., Bosworth G. 2010. Exploring the strategic skills of farmers across a typology of farm diversification approaches. Journal of Farm Management. Vol. 13(12). P. 819-838.

13. Nedergaard N., Jones R. 2011. Implementing Firm Dynamic Capabilities through the Concept Design Process: A Conceptual Model for Creating Sustainable Competitive Advantage. Australian \& New Zealand Marketing Academy Conference (ANZMAC) 2011 [žiūrèta 2013-0916]. Prieiga per internetą: <http://anzmac.org/ conference/2011/Papers\%20by\%20Presenting\%
20Author/Nedergaard,\% 20Nicky\% 20Paper\% 20514.pdf>

14. Teece D. J., Pisano G., Shuen A. 1997. Dynamic capabilities and strategic management. Strategic Management Journal. Vol. 18(7). P. 509-533.

15. Teece D. J. 2007. Explicating dynamic capabilities: the nature and microfoundations of (sustainable) enterprise performance. Strategic Management Journal. Vol. 28(13). P. 1319-1350.

16. Ükiu veiklos rezultatai / FADN survey results. 2011 (ŪADT tyrimo duomenys). Vilnius: Lietuvos agrarinès ekonomikos institutas, 2012. 108 p.

17. Van der Ploeg J., Jingzhong Y., Schneider S. 2010. Rural development reconsidered: building on comparative perspectives from China, Brazil and the European Union. Rivista di Economia Agraria. Vol. LXV. No. 2.

\section{Dalia Vidickienė, Rasa Melnikienė, Živilè Gedminaitè- Raudonè}

\section{PRACTICE OF APPLYING MANAGEMENT METHODS BY LITHUANIAN FARMERS}

Sum mary

Dynamic agricultural environment and new challenges due to climate change and lack of stability in the markets require farmers to increase their knowledge and flexibility in applying management methods. This paper presents research results on the assessment of management methods applied by Lithuanian farmers with the aim to demonstrate the differences in practices of applying management methods depending on the type of the farm: comparing practices in the farms that produce only primary agricultural production and supply raw materials to the processing industry and in the farms that are willing to exploit new market opportunities and perform primary processing, sell production to the customers, offer other services and use various ways to diversify economic activities in the farm. The research was based on the evolutionary approach for the practices of applying management methods by using systemic analysis and questionnaire methods. The survey results indicate that Lithuanian farmers are acquiring management knowledge from the simplest to the more sophisticated management methods and support the evolutionary approach to learning and teaching processes.

Key words: evolutionary approach, basic financial analysis and planning, tactical and operational planning, strategic planning and management 